\title{
Leaf morphoanatomy of an endemic massaranduba from Chapada Diamantina, Bahia, Brazil
}

\author{
Monick Lima Carvalho ${ }^{1} \mathbb{D}$ \& Cláudia Elena Carneiro ${ }^{1}[\mathbb{C}$ \\ ${ }^{1}$ Universidade Estadual de Feira de Santana, Departamento de Ciências Biológicas, Av. Transnordestina, s/n, \\ Novo Horizonte, 44036-900, Feira de Santana, BA, Brasil. \\ *Corresponding author: monickcarvalho33@gmail.com
}

CARVALHO, M.L., CARNEIRO, C.E. Leaf morphoanatomy of an endemic massaranduba from Chapada Diamantina, Bahia, Brazil. Biota Neotropica 21(3): e20201187. https://doi.org/10.1590/1676-0611-BN-2020-1187.

\begin{abstract}
The Sapotaceae family is recognized for its economic importance, presenting food, medicinal and timber potential. Pouteria andarahiensis T.D.Penn., popularly known as "massaranduba", is endemic to Chapada Diamantina, Bahia, Brazil, and is currently classified on the IUCN red list as "endangered". Pouteria andarahiensis is little studied, highlighting this work as the first anatomical study for the species. Light microscopy and scanning electron microscopy techniques were used to perform anatomical studies. The species showed characters shared with the family (laticifers and malpiguiaceous trichomes), as well as diagnostic characters and associated with xeromorphy. The data obtained from the leaf architecture can assist in the identification of the species in a vegetative state, while the leaf surface provided unpublished data to the species, indicating the presence of a cuticle with complex ornamentation. Stand out as xeromorphic anatomical features, high stomatal density, high number of trichomes per area, sclerenchymatic columns in the mesophyll and a subepidermal sclerenchyma layer connecting the vascular bundles in the mesophyll.

Keywords: Leaf anatomy; Chrysophylloideae; Xeromorphy.

\section{Morfoanatomia foliar de uma massaranduba endêmica da Chapada Diamantina, Bahia, Brasil}

Resumo: A família Sapotaceae é reconhecida pela sua importância econômica, apresentando potencial alimentício, medicinal e madeireiro. A espécie Pouteria andarahiensis T.D.Penn., conhecida popularmente como "massaranduba", é endêmica da Chapada Diamantina, Bahia, Brasil, e atualmente encontra-se classificada na lista vermelha da IUCN como "em perigo". Pouteria andarahiensis é pouco estudada, destacando este trabalho como o primeiro estudo anatômico para a espécie. Foram empregadas técnicas de microscopia de luz e de microscopia eletrônica de varredura para a realização dos estudos anatômicos. A espécie apresentou caracteres compartilhados com a família (laticíferos e tricomas malpiguiáceos), assim como, caracteres diagnósticos e associados a xeromorfia. Os dados obtidos da arquitetura foliar podem auxiliar na identificação da espécie em estado vegetativo, enquanto a superfície foliar forneceu dados inéditos a espécie, indicando a presença de uma cutícula com ornamentação complexa. Destacam-se como características anatômicas xeromórficas, alta densidade estomática, alto número de tricomas por área, colunas esclerenquimáticas no mesofilo e uma camada subepidérmica de esclerênquima conectando os feixes vasculares no mesofilo.

Palavras-chave: Anatomia foliar; Chrysophylloideae; Xeromorfia. 


\section{Introduction}

The genus Pouteria Aubl. belongs to the subfamily Chrysophylloideae and stands out within the Sapotaceae family for presenting about 200 species, with 128 occurring in Brazil (Carneiro \& Almeida Jr. 2010; Carneiro et al. 2015, Alves-Araújo et al. 2020), in which 52 are endemic. Pouteria andarahiensis T.D.Penn. is characterized by the shrub or arboreal habit; presence of white latex in the branches, leaves and fruits; petiolate leaves, simple, leathery texture, alternating-spiral, which have ferruginous trichomes; inflorescences with 3-12 flowers, axillary, and unisexual flowers. Pouteria andarahiensis can be identified in the presence of its reproductive organs, however, its vegetative characters demonstrate morphological uniformity with other species of the genus, making it difficult to identify sterile species.

Pouteria andarahiensis is endemic to Chapada Diamantina, occurring in regions of caatinga and cerrado, composing the rupestrian field vegetation, being popularly known as "massaranduba" (Pennington 1990). According to the National Flora Conservation Center (CNCFLORA 2020) Pouteria andarahiensis occupies an occurrence extension of 46,376.90 $\mathrm{km}^{2}$, being protected by the Chapada Diamantina National Park.

However, the area of occurrence of the species has been suffering continuous degradation due to factors that date back to the diamond and gold mines, or even, by the use of fire used to open pastures for cattle breeding, the expansion of agricultural areas and also the demand for wood, which is commonly used for construction (Funch et al. 2005; Nascimento et al. 2010). This reduction in the area of occupation, as well as the use of timber, included $P$. andarahiensis in the red list of the International Union for Conservation of Nature - IUCN (O'Brien 1998), being classified as "endangered" (EN).

The species of the genus Pouteria are known for presenting compounds used in medicine and in the production of cosmetics, for the use of their fruits in food, the use of latex in the production of rubber and gum, and for the use of wood in constructions. The realization of morphological studies, mainly that address the internal structure, may indicate whether the species has medicinal, commercial and ecological potential, as observed in other representatives of the genus.

Cabral et al. (2016) consider that the leaves present characteristics as useful for the identification of species as their floral characters and the pollen morphology, while Roth-Nebelsick et al. (2001) consider the architecture of leaf venation an important character for the taxonomic classification. In this context, the morphology and anatomy of Pouteria andarahiensis leaves were used to provide distinctive characters for the species in a vegetative state and, consequently, to support its taxonomy and assist in the knowledge of Northeastern flora.

\section{Material and Methods}

This work was based on the material collected in the municipality of Morro do Chapéu, as well as analysis of the material deposited in the Herbarium of the State University of Feira de Santana (HUEFS). Samples in good condition and with fully expanded leaf blades were selected.

To obtain the leaf architecture, Strittmatter's (1973) diaphanization technique was used. The samples obtained were stained with $1 \%$ aqueous safranin and kept in glass plates with 50\% glycerin (Kraus \& Arduin 1997). The measurements of the veins were carried out in three regions of the leaf blade (base, middle, apex) through the micrometric eyepiece of the Zeiss Primo Star light microscope in all diaphanized specimens, and for descriptive analysis the terms of classification by Ash et al. (1999) were used.
The study of leaf epidermis was performed using scanning electron microscopy and light microscopy. For analysis in a scanning electron microscope (SEM), segments of the median region of the leaves stored in ethyl alcohol were dried in an oven at $60^{\circ} \mathrm{C}$, and then covered with $18 \mathrm{k}$ gold powder in a Denton Vacuum IV metallizer. The samples were analyzed using a JSM-6390LV scanning electron microscope. For analysis under a light microscope, the epidermis was obtained using two methodologies, the Foster technique (Macêdo 1997) in whole and fractionated leaves, and the Jeffrey technique (Macêdo 1997) only for whole leaves, verifying the obtainment of the best results in fractional leaves submitted to the Foster technique. The obtained epidermis was stained with $1 \%$ aqueous safranin and mounted on semi-permanent slides according to the manual by Kraus \& Arduin (1997). The cuticle description viewed through SEM was based on the classification and terminology used by Barthlott et al. (1988) for epicuticular waxes, and the description of the epidermis was based on the terminology used by Solereder (1908). For the metric data of the leaf epidermis, two methods were used. For counting the number of cells, stomata and trichome scars, 20 areas (10 fields on the adaxial face and 10 on the abaxial face) of 5 slides for each specimen were photographed with the aid of a Leica ICC50 W camera attached to the Leica DM500 microscope, being used to Pouteria andarahiensis 2 specimens from herbarium and 2 specimens of fresh material.

For the measurements of cells and stomata, the same slides were used to count the number of cells in the Zeiss Primo Star microscope with the aid of the micrometric eyepiece, where 5 cells and 5 stomata (on the abaxial face) were measured for each of the 20 counted fields.

To analyze the internal structure, the material was transversally sectioned by freehand and with a freezing microtome in the base, middle, apex, border and petiole regions (distal, median and proximal regions). For samples sectioned in a freezing microtome, distilled water was used as the inclusion medium. The material was sectioned at $25 \mu \mathrm{m}$ thick, using the Leica $\mathrm{CM} 1860$ cryostat at $-26^{\circ} \mathrm{C}$. The samples were clarified in commercial sodium hypochlorite, stained with $1 \%$ astra blue and $1 \%$ safranin in the 9: 1 ratio (Bukatsch 1972), or 1\% alcian blue and 1\% safranin (Luque et al. 1996), and mounted on semi-permanent slides (Kraus \& Arduin 1997). The analysis of the samples was performed in a Zeiss Primo Star light microscope, and the images were obtained with the Leica ICC50W camera coupled to the Leica DM500 microscope. For the metric data of the anatomical samples, 20 fields of 5 slides of each specimen used were counted, made with cross sections of the leaf blade and the petiole, being 10 fields of the adaxial side and 10 of the abaxial side. To determine the degree of cuticle thickness, it was measured using the micrometric eyepiece of the Zeiss Primo Star microscope, using the following classification method: cuticles with $1.0 \mu \mathrm{m}<2.0 \mu \mathrm{m}$ were considered thin, $\geq 2.0 \mu \mathrm{m}<4.0 \mu \mathrm{m}$ were considered medium thickness, $\geq 4.0 \mu \mathrm{m}$ were considered thick. Cross-sectional measurements of the palisade parenchyma cells were also performed. The terminology used in the anatomical descriptions was based on Metcalfe \& Chalk (1972); Howard (1979) and Theobald et al. (1979), for leaf shape, petiole and trichomes, respectively.

\section{Results}

Pouteria andarahiensis T.D.Penn. has a shrub or arboreal habit and trees up to 6 meters high can be found (Figure 1A), with whitish milky latex common to the family occurring on the trunk, branches, 
leaves and fruits. The leaves are simple, leathery, alternating spiral, and with non-channeled petiole. The leaf blade has an elliptical to ovate shape, acute to obtuse apex, attenuated base, whole revolute margin (Figure 1B), shows trichomes on both sides in young leaves, and loses these trichomes in adult leaves, being thus considered glabrescent.

The leaves are peninerved, camptodromous of the brochidodromous type, with midrib showing straight development and high caliber gradually tapering towards the apex with a diameter ranging from $1 \mathrm{~mm}$ at the base to $0.2 \mathrm{~mm}$ at the apex. The secondary veins are presented in eight to ten pairs, which originate from the midrib alternately, with straight development that form arcs at the ends. The intersecondary veins are found in the median region between the secondary veins, developing in parallel and connected to the secondary ribs through the tertiary veins. The tertiary veins are inserted in the secondary veins at straight angles, alternating, forming a sinuous pattern that can present secondary arcs when connected to other tertiary or quaternary veins. Tertiary and smaller caliber ribs are present outside the arches formed by the secondary veins, presenting the same reticulated pattern as the rest of the leaf. It was possible to see veins of up to fifth order and free terminal venules (Figure 1C).

In cross-section, the petiole of the Pouteria andarahiensis is biconvex, the cuticle is thick, the epidermis is unistratified and the anticline walls straight, it has six to seven layers of angular collenchyma below the epidermis in the cortical region and the medulla has filling parenchyma (Figure 1D). The central vascular bundle is closed, planeconvex, with the phloem and xylem arranged in parallel rows and the medulla of the vascular bundle is filled with parenchyma (Figure 1E). Accessory bundles may or may not occur and, when present, vary from one to two, anastomosed through the sclerenchyma sheath that surrounds the vascular bundle. Laticifers are seen in the center of the vascular bundle, between the elements of the phloem and throughout the cortical region. There were no differences between the distal, median and proximal regions of the petiole.

The leaf blade of Pouteria andarahiensis has a cuticle with complex ornamentation, with platelets covering the stretch marks and guard cells of the stomata, forming slight elevations on the leaf surface (Figure 1F). These platelets are distributed over the guard cells perpendicularly and longitudinally over the stretch marks. These stretch marks can also be viewed under light microscopy, using the extracted epidermis, where it was observed that these stretch marks are less prominent in the costal cells. Through the transverse sections, a thickened cuticle layer about $16-20.8 \mu \mathrm{m}$ on the adaxial face and 6.4-19.2 $\mu \mathrm{m}$ on the abaxial face, with unistratified epidermis and presenting differentiated cells, was visualized under light microscopy close to the main rib on the adaxial face, being square and smaller and on the rest of the blade elongated and with tabular shape, while in the abaxial face are rounded and uniform (Figure 1G).

Through light microscopy it was found that the intercostal epidermal cells have a rectangular and polygonal shape on both sides, with a larger diameter on the abaxial face, with about $40 \mu \mathrm{m} \times 15 \mu \mathrm{m}$ and about 645 cells per $\mathrm{mm}^{2}$, while on the adaxial face, have a smaller diameter and are more numerous, measuring an average of $19.5 \mu \mathrm{m} \times 16.6 \mu \mathrm{m}$ with about 1,908 cells per $\mathrm{mm}^{2}$. The costal epidermal cells on the abaxial surface are larger and rectangular, approximately $60 \mu \mathrm{m} \times 14.5 \mu \mathrm{m}$. The anticline walls are straight (Figure 1H-I).

$P$. andarahiensis is hypoestomatic, and the stomata are anisocytic type. In cross-section, the stomata are on the same level as the epidermal cells, widely distributed among intercostal cells, with about 61 stomata per $\mathrm{mm}^{2}$, and may rarely occur between the costal cells. Pouteria andarahiensis presented simple non-glandular trichomes (tectors), in " $T$ " shape, known as malpighiaceous trichomes, on both sides, with greater concentration on the abaxial surface, presenting an average of 26 trichomes per $\mathrm{mm}^{2}$, while on the adaxial surface, it presents 5 trichomes per $\mathrm{mm}^{2}$ (Figure 1J). These trichomes are distributed over intercostal and costal cells, being more abundant in intercostal cells, with four to five cells at the base.

The mesophyll is dorsiventral, composed of two layers of palisade parenchyma and six to seven layers of spongy parenchyma, the cells of the palisade parenchyma are elongated, juxtaposed transversely to the epidermis and with straight anticline walls. The spongy parenchyma is formed by cells of irregular shape, provided with braciform projections forming intercellular spaces of varying dimensions. On average, the mesophyll is $341.8 \mu \mathrm{m}$ thick, with the palisade parenchyma about $124.8 \mu \mathrm{m}$ thick and the spongy parenchyma is about $147.2 \mu \mathrm{m}$, where the cells of the palisade parenchyma measure about $56 \mu \mathrm{m} \times 14,4 \mu \mathrm{m}$. The vascular bundles present in the mesophyll are accompanied by sclerenchyma cells forming a sheath surrounding these bundles which extends forming a subepidermal layer that connects the lateral bundles (Figure $1 \mathrm{~K}$ ). Laticifers are present in the spongy parenchyma and associated with vascular bundles (Figure $1 \mathrm{G}-\mathrm{K}$ ).

In cross section in the median region of the leaf, the leaf blade exhibits a biconvex shape, being more prominent on the abaxial face. The epidermal cells in the midrib region do not differ when compared to the epidermal cells of the rest of the leaf blade. The cortical region consists of six to seven layers of angular collenchyma on the adaxial surface and eight to nine layers on the abaxial surface. The simple parenchymal tissue fills the entire remaining cortical region, and on the adaxial surface it transitions to the palisade parenchyma when approaching the mesophyll. It is possible to identify laticifers throughout the cortex and idioblasts have been identified in the cortex, on the abaxial face. The vascular system is in the form of a continuous arch, flat-convex, where the phloem and xylem are organized in parallel rows, being able to visualize the presence of laticifers between the phloem elements, and the medulla is filled with parenchymatic tissue that contains laticifers. The vascular system may or may not have accessory bundles, when present they are from one to three anastomosed through the sheath elements of perivascular sclerenchyma cells.

The leaf edge is flexed, the epidermal cells of the adaxial face when viewed in cross section, are rectangular arranged in parallel and are narrowing as they approach the distal portion, on the abaxial face the epidermal cells are polygonal and smaller than on the adaxial face, the palisade parenchyma has two layers of cells arranged in parallel and seven to eight layers of spongy parenchyma with braciform projections. In the distal portion of the border, the parenchyma gradually loses the distinction between palisade and lacunous and appears as a homogeneous tissue with rounded cells, where the presence of laticifers was verified (Figure 1L).

\section{Discussion}

Pouteria andarahiensis is a difficult species to identify based only on vegetative characters, because in the absence of fertile material its morphology is very similar to other species of the genus and family. 

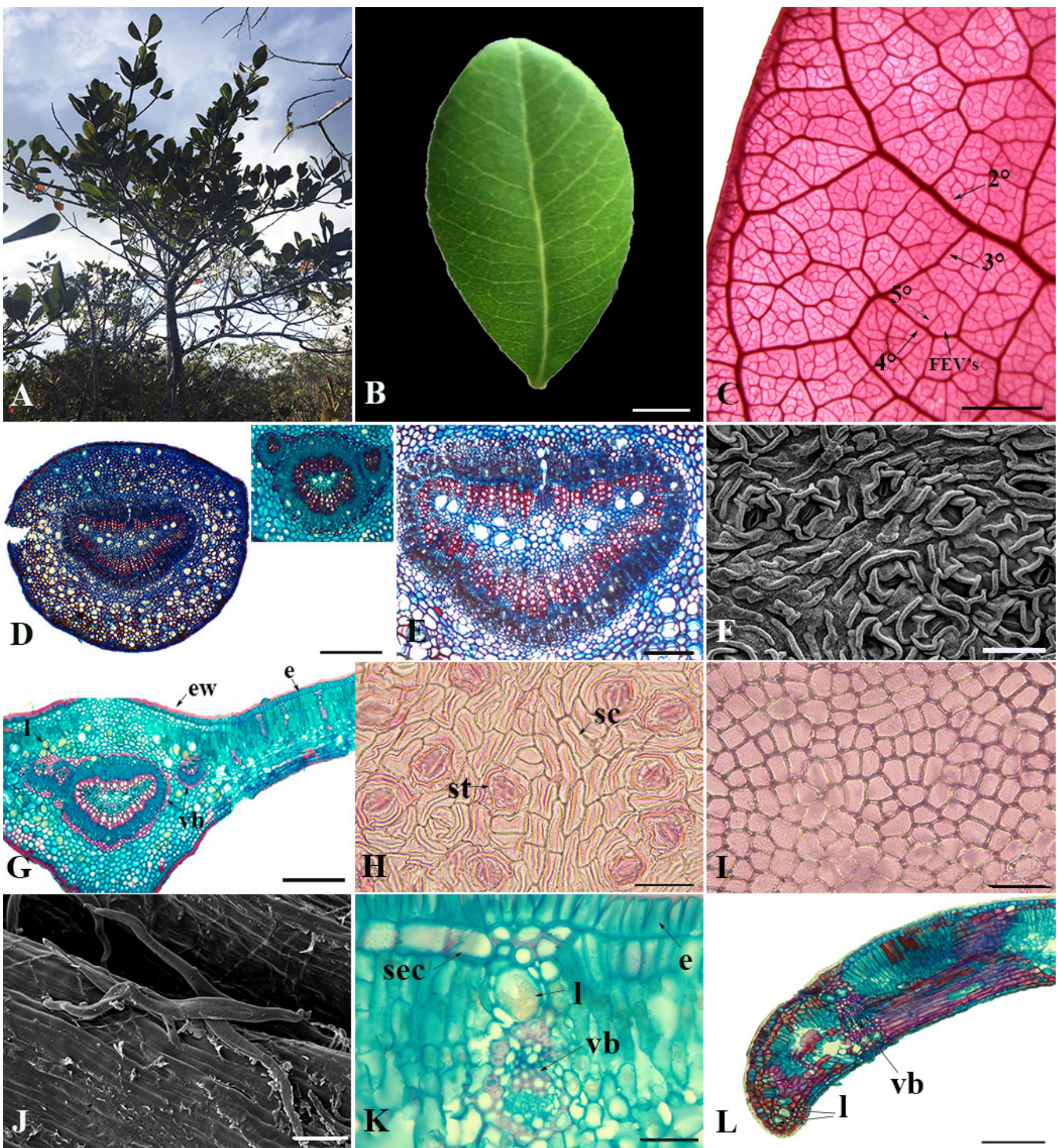

Figure 1. A - Individual of Pouteria andarahiensis T. D. Penn. B - Leaf. C - Part of the diaphanized leaf, showing the second to fifth order veins and the free terminal venules (FEV's). D - Cross section of the median region of the biconvex petiole. E - Cross section of the petiole showing the closed vascular bundle. F - Complex cuticle of the abaxial face, composed of streaks and platelets with patterns of organization in scanning electron microscopy. G - Cross section of the median region of the leaf, showing the cuticle (ew), the epidermis (e), the laticifers (l) and the vascular bundles (vb). H - Leaf epidermis of the abaxial face, showing stomata (st) and stretch marks (sc) under light microscopy. I - Leaf epidermis of the adaxial face. J - T-shaped malpiguiaceous trichome in scanning electron microscopy. K Cross section of the mesophyll, showing the epidermis (e), the laticifers (l), the subepidermal cell layer (sec) and the vascular bundle (vb). L - Transverse section of the border, showing the laticifers (1) in the distal portion, and the vascular bundle (vb). Scale: B $1 \mathrm{~cm}$; C 2 mm; D, G $500 \mu \mathrm{m}$; E - L $200 \mu \mathrm{m}$; F, H - K $50 \mu \mathrm{m}$. 
Although identification through reproductive characters is effective for most species, it is extremely important to correctly identify a species based only on vegetative characters. According to Roth-Nelbelsick et al. (2001) it is beneficial to use topological aspects to characterize the patterns of leaf venation, since these are unequivocal, therefore, using the pattern of leaf venation found in Pouteria andarahiensis can be considered a reliable method to identify specimens in vegetative state. Schulz \& Hilgenfeldt (1994) use the term "dendritic structure" to define the venation pattern found in Pouteria andarahiensis. Using the standardization of leaf venation classification by Hickey $(1974,1979)$, veins were considered up to fifth order, since the simplest venations form reticles that do not allow differentiation in caliber. Although Pouteria andarahiensis leaves present many macroscopic differences when compared to other genera of the family, in microscopic character the leaf architecture still manages to present many similarities between them. Studies were carried out that described the leaf venation of Diploon's species (Lima et al. 2019) and of Manilkara's species (Almeida-Jr et al. 2013), where similarities were found with the results of this work. The brochidodromous venation, with single primary vein, secondary veins originating from the primary vein without reaching the margin, with one or more intersecondary veins, were characters of Pouteria andarahiensis shared with Diploon species. The straight tertiary veins was the only characteristic of Pouteria andarahiensis found similar in the species of Manilkara. Differently the leaf architecture, the characters found in the petiole of $P$. andarahiensis presented similarities to the results found by Almeida-Jr et al. (2013) for Manilkara species, such as, circular shape, the format of the flat-convex vascular bundle and the accessory bundles when present, occurring in number of one or two. However, when compared to the characters found in the petiole in the genus Diploon (Lima et al. 2019), similarities were found in the shape of the flat-convex vascular bundle, the occurrence of accessory bundles in number of one or two and the presence of laticifers in the medullary region. The flat-convex vascular bundle shape found in the petiole of $P$. andarahiensis can also be verified in $P$. beaurepairei, however, Monteiro et al. (2007) verified that the vascular bundle shape presents a lot of variation, being able to visualize biconvex, flat-convex, flat and slightly convex vascular bundles for Pouteria species from Rio de Janeiro.

The characters used to identify species of the family in a vegetative state described by Solereder (1908) and by Metcalfe \& Chalk (1957), are present in Pouteria andarahiensis, being easily distinguished by the presence of latex and malpighiaceous trichomes. The thick cuticle in Pouteria andarahiensis may be related to the environment in which it is found, as according to Figueiredo et al. (2012) and Gutschick (1999) the thick cuticle helps stomata against water loss in periods of dry and are present in plants with a xeromorphic character, this thick and extremely striated cuticle resembled that found by Monteiro et al. (2007) for Pouteria ramiflora, however, it differed from all other Pouteria species studied for the Rio de Janeiro state. The similarity found between Pouteria andarahiensis and Pouteria ramiflora may be related to the environment in which they occur, since both can be found in Cerrado, in regions with sandy soil. The work of Popovkin et al. (2016) for Pouteria synsepala, also presented a cuticular pattern similar to that found in Pouteria andarahiensis, where the cuticle forms labyrinths around stomata that are at the same level as the cuticle, however, the formation of stretch marks in the cuticle is more evident in Pouteria andarahiensis. Barthlott et al. (1998), describe the shape of the platelets as flat crystals, with an entire margin and regular shape, according to him, these platelets may have characteristic orientation patterns. Therefore, when present, these patterns are important to characterize a surface, in Pouteria andarahiensis the platelets deposited on the guard cells are oriented perpendicularly to the ostioles and those deposited on the stretch marks are oriented along their length. The pattern of organization of the platelets on the stretch marks can be classified as parallel and those found on guard cells would have a pattern of locally restricted orientation, these patterns can be used as taxonomic markers, since these have remained constant in all specimens analyzed.

Regarding the diagnostic characters of the family, trichomes are numerous in young leaves of P. andarahiensis, and according to Press (1999) in hot and arid environments, the main role of trichomes is to decrease leaf temperature and water loss, decreasing the absorption of solar radiation, and hypoestomatic leaves with anisocytic stomata are in accordance with several works for the family and genus (Solereder 1908; Metcalfe \& Chalk 1957; Pennington 2004; Monteiro et al. 2007; Leite et al. 2017), these stomata are numerous, which Wilkinson (1979) relates to xerophyte species.

The outline of the anticline walls of the epidermal cells is straight, which corroborates with Santiago et al. (2001) who correlated leaves exposed to the sun to the presence of epidermal cells with straight anticline walls, since $P$. andarahiensis is exposed to frequent sunlight.

The mesophyll with dorsiventral disposition found in P. andarahiensis corroborates the description of Metcalfe \& Chalk (1957) for the family and with the data found by Monteiro et al. (2007), Almeida Jr. (2013); Leite et al. (2017) and Lima et al. (2019), for other species of Sapotaceae. It is possible to visualize sclerenchyma columns in the mesophyll, these columns together with the thick cuticle, may be related to long periods of drought, strong light and poor nutrient soil (Dickison 2000; Cutler et al. 2011).

Solereder (1908) affirms that the vascular bundles present in the mesophyll can connect vertically through a layer of cells that can be sclerenchymatic or parenchymal, and in the present study it was found that in $P$. andarahiensis, it presents this connection between the columns by a layer sclerenchymatic cells that appear around the vascular bundles and form a layer below the epidermis, connecting to the nearest vascular bundle.

\section{Conclusion}

Unpublished data about $P$. andarahiensis, an endemic species of the Chapada Diamantina, were presented, such as platelets with patterns of organization present in the cuticle, subepidermal cell layer, anisocytic stomata and malpiguiaceous trichomes common to the family and sclerenchyma cell sheath that surround the vascular bundles, that can be used for its identification in a vegetative state, in addition, it was possible to verify that the species has mechanisms of adaptation to xeromorphic environments, such as the presence of ornamented cuticle, high stomatal density, high number of trichomes per area and sclerenchyma columns in the mesophyll.

\section{Acknowledgements}

This work was carried out with the support of the Coordenação de Aperfeiçoamento de Pessoal de Nível Superior - Brasil (CAPES) - Finance Code 001, the Programa de Pós-Graduação em Recursos Genéticos Vegetais (PPGRGV), the Laboratório de Micromorfologia Vegetal (LAMIV) and the Universidade Estadual de Feira de Santana (UEFS). 


\section{Author Contributions}

Monick Lima Carvalho: Substantial contribution in the concept and design of the study; Contribution to data collection; Contribution to data analysis and interpretation; Contribution to manuscript preparation; Contribution to critical revision, adding intellectual content.

Cláudia Elena Carneiro: Substantial contribution in the concept and design of the study; Contribution to data collection; Contribution to data analysis and interpretation; Contribution to critical revision, adding intellectual content.

\section{Conflicts of Interest}

The authors declare that they have no conflict of interest related to the publication of this manuscript.

\section{References}

ALMEIDA-JR, E. B., ARAÚJO, J. S., SANTOS-FILHO, F. S., \& ZICKEL, C. S. 2013. Leaf morphology and anatomy of Manilkara Adans. (Sapotaceae) from northeastern Brazil. Plant Systematics and Evolution, 299(1): 1-9.

ALVES-ARAÚJO, A.; MONTEIRO, M. H. D. A.; FARIA, A. D. \& RIBEIRO, J.E.L.S. Pouteria in Flora do Brasil 2020 em construção. Jardim Botânico do Rio de Janeiro. Disponível em: <http://floradobrasil.jbrj.gov.br/reflora/ floradobrasil/FB14492>. (Last access in: 17/06/2020).

ASH, A.; ELLIS, B.; HICKEY, L. J.; JOHNSON, K.; WILF, P.; WING, S. 1999. Manual of leaf architecture: morphological description and categorization of dicotyledonous and net-veined monocotyledonous angiosperms. Smithsonian Institution.

BARTHLOTT, W., NEINHUIS, C., CUTLER, D., DITSCH, F., MEUSEL, I., THEISEN, I., \& WILHELMI, H. 1998. Classification and terminology of plant epicuticular waxes. Botanical Journal of the Linnean Society, 126(3): 237-260.

BUKATSCH, F. 1972. Bemerkungen zur Doppelfarbung Austrablau Safranin. Mikrokosmos, 61:255.

CABRAL, L. O., FERREIRA, H. D., VILHALVA, D. A., \& FARIA, M. T. 2016. Arquitetura foliar de espécies arbóreas do bosque Auguste de Saint-Hilaire, Goiânia, Goiás, Brasil. RENEFARA, 9(9): 1-22.

CARNEIRO, C. E., ALMEIDA JR., E. B. 2010. Sapotaceae. In Lista de Espécies da Flora do Brasil. Jardim Botânico do Rio de Janeiro. (http://floradobrasil. jbrj.gov.br/2010/FB014492).

CARNEIRO, C. E., ALVES-ARAÚJO, A., ALMEIDA JR., E. B. \& TERRAARAUJO, M. H. 2015. Sapotaceae in Lista de Espécies da Flora do Brasil Jardim Botânico do Rio de Janeiro. (http://floradobrasil.jbrj.gov.br/jabot/ floradobrasil/FB217) (Last access in 21/06/2019).

CNCFlora. Pouteria andarahiensis in Lista Vermelha da Flora Brasileira versão 2012.2 Centro Nacional de Conservação da Flora. Disponível em (http:// cncflora.jbrj.gov.br/portal/pt-br/profile/Pouteria\%20andarahiensis) (last acess in 04/10/2020).

CUTLER, D. F.; BOTHA. T. \& STEVENSON, D. W. 2011. Anatomia vegetal - uma abordagem aplicada. Porto Alegre: Artmed. 304p.

DICKISON, W.C. 2000. Integrative plant anatomy. San Diego: Harcourt Academic Press. 533p.

FIGUEIREDO, K. V., OLIVEIRA, M. T., OLIVEIRA, A. F. M., SILVA, G. C., \& SANTOS, M. G. 2012. Epicuticular-wax removal influences gas exchange and water relations in the leaves of an exotic and native species from a Brazilian semiarid region under induced drought stress. Australian Journal of Botany, 60(8): 685-692.

FUNCH, L.S.; FUNCH, R.R.; HARLEY, R.; GIULIETTI, A.M.; QUEIROZ, L.P.; FRANÇA, F.; MELO, E.; GONÇALVES, C.N. \& SANTOS, T. 2005. Florestas estacionais semideciduais. In: Juncá, F.A.; Funch, L. \& Rocha, W. (ed.). Biodiversidade e conservação da Chapada Diamantina. Ministério do Meio Ambiente, Brasília. Pp. 181-193

GUTSCHICK, V.P. 1999. Biotic and abiotic consequences of differences in leaf structure. The New Phytologist, 143(1): 3-18.

HICKEY, L.J. 1974. Clasificación de la arquitectura de las hojas de dicotiledoneas. Boletin de la Sociedad Argentina de Botánica, 16(1-2): 1-26.
HICKEY, L.J. 1979. A revised classification of the architecture of dicotyledonous leaves. Pp. 25-39. In: C.R. Metcalfe \& L. Chalk. Anatomy of the Dicotyledons - systematic anatomy of the leaf and stem. v. I., 2 ed. London, Oxford University Press.

HOWARD R.A. 1979. The petiole. In: Metcalfe CR, Chalk L (eds), Anatomy of the dicotyledons: systematic anatomy of the leaf and stem, vol 1, 2 ed. Oxford Claredon, Oxford, pp 88-96.

KRAUS, J.E. \& ARDUIN, M. 1997. Manual básico de métodos em morfologia vegetal. Rio de Janeiro, EDUR.

LEITE, M. S., SILVA, F. G., ASSIS, E. S., RUBIO NETO, A., MENDES, G. C., \& ROSA, M. 2017. Morphoanatomy and physiology of Pouteria gardneriana Radlk plantlets grown in vitro at varied photosynthetic photon flux densities. Acta Scientiarum. Agronomy, 39(2): 217-224.

LIMA, R.G. V. N.; LIMA, L.F.; FERREIRA, A. C.; ARAÚJO, J. S. \& ZICKEL, C. S. 2019. Leaf Morphoanatomy of Diploon Cronquist (Sapotaceae Juss.). Biota Neotropica, 19(1): 1-7. https://doi.org/10.1590/1676-0611bn-2018-0600 (last access in 29/12/2020).

LUQUE, R.; SOUSA, H. C. DE \& KRAUS, J. E. 1996 Métodos de coloração de Roeser (1972): modificado - e Kropp (1972) visando a substituição do azul de astra por azul de alcião 8GS ou 8GX. Acta Botanica Brasilica, 10(2): 199-212.

MACÊDO, N.A. 1997. Manual de Técnicas em Histologia Vegetal. Feira de Santana, Universidade Estadual de Feira de Santana.

METCALFE, C. R. \& CHALK, L. 1957 Anatomy of the Dicotyledons. Vol II. Oxford: Claredon Press. 557 p.

METCALFE, C. R. \& CHALK, L. 1972. Anatomy of the Dicotyledons. Vol I. Oxford: Claredon Press. 1500 p.il.

MONTEIRO, M. H. D. A., DE JESUS NEVES, L., \& ANDREATA, R. H. P. 2007. Levantamento e distribuição das espécies de Pouteria Aubl. (Sapotaceae) do Estado do Rio de Janeiro, Brasil. Revista Brasileira de Biociências, 5(S2): 369-371.

NASCIMENTO, F. H. F. D., GIULIETTI, A. M., \& QUEIROZ, L. P. D. 2010. Diversidade arbórea das florestas alto montanas no Sul da Chapada Diamantina, Bahia, Brasil. Acta Botanica Brasilica, 24(3): 674-685.

O'BRIEN, J.P. 1998. Pouteria andarahiensis. The IUCN Red List of Threatened Species 1998:http://dx.doi.org/10.2305/IUCN.UK.1998.RLTS. T35801A9957420.en Downloaded on 28 May 2019.

PENNINGTON, T.D. 1990. Sapotaceae. Flora Neotropica, Monograph 52: 1 - 770.

PENNINGTON, T.D. 2004. Sapotaceae (Sapodilla family). In: N. Smith; S.A. Mori; A. Henderson; D.W. Stevenson; S.V. Heald (eds.). Flowering plants of the Neotropics. Princeton: Princeton University Press, p. 342-344.

POPOVKIN, ALEX V.; FARIA, A. D. \& SWENSON, U. 2016. Pouteria synsepala (Sapotaceae: Chrysophylloideae): a new species from the northern littoral of Bahia, Brazil. Phytotaxa, 286(1): 39-46.

PRESS, M. C. 1999. The functional significance of leaf structure: a search for generalizations. The New Phytologist, 143(1): 213-219.

ROTH-NEBELSICK, A., UHL, D., MOSBRUGGER, V., \& KERP, H. 2001. Evolution and function of leaf venation architecture: a review. Annals of Botany, 87(5): 553-566.

SANTIAGO, E. J. A., PINTO, J. E. B. P., DE CASTRO, E. M., LAMEIRA, O. A., DACONCEIÇÃO, H.E. O., \& GAVILANES, M. L. 2001. Aspectos da anatomia foliar da pimenta-longa (Piper hispidinervum C. DC.) sob diferentes condições de luminosidade. Ciência e Agrotecnologia, 25:1035-1042.

SCHULZ, H. C. \& HILGENFELDT, S. 1994. Experimente zum Chaos. Spektrum der Wissenschaft 1: 72-81.

SOLEREDER, H. 1908. Systematic anatomy of the dicotyledons. Oxford, Clarendom Press. 1182p.

STRITTMATTER, C. D. 1973. Nueva técnica de diafanización. Boletín de la Sociedad Argentina. 15(1): 126-129.

Received: 09/01/2021

Revised: $18 / 05 / 2021$

Accepted: 23/05/2021

Published online: 18/06/2021 